
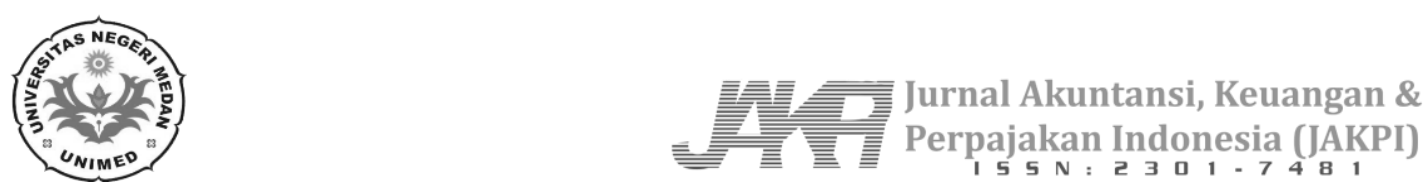

\title{
Pengaruh Corporate Social Responsibility Terhadap Earning Quality Pada Perusahaan Pertambangan Yang Terdaftar Di Bursa Efek Indonesia
}

Tahun 2015 - 2017

\author{
Supriani Hutasoit ${ }^{1}$, Khairunnisa Harahap ${ }^{2}$, Akmal Huda Nst. ${ }^{3}$ \\ Fakultas Ekonomi UNIMED \\ nisaharahap@yahoo.com
}

\begin{abstract}
The problem in this research is that the number of companies conducting corporate social responsibility (CSR) at the moment to get a positive image of the parties concerned with the sustainability of the company. On the other hand, management can also perform actions such as earnings management practices. Therefore, this study aimed to examine whether the company contributes to corporate social responsibility (CSR) tend to avoid actions kualitias profit management resulting in better profit or otherwise. In this study aimed to examine the effect of disclosure of corporate social responsibility towards the quality of earnings in mining companies listed on the Indonesia Stock Exchange 2015-2017.The study population was a mining company listed on the Stock Exchange in 2015-2017 as many as 42 companies. Samples are 12 companies with purposive sampling method, with quantitative research. The data used is secondary data, the company's financial statements were obtained from www.idx.co.id, https://finance.yahoo.com, as well as from the company's official website. The data analysis technique used is descriptive statistics, normality test, assuming classical, multiple regression analysis, the coefficient of determination, F-statistics test and t-test statistics.The dependent variable in this study is the quality of earnings through proxied using discretionary accruals (DAC). The independent variable used is CSR and CSR Index (CSRI) using GRI guidelines. This study also uses control variables firm size, leverage, and profitability. The analytical method used in this research is regression analysis with SPSS 20. Based on the results of this study to simultaneously show that CSR variables significantly influence the quality of earnings through discretionary accruals (DAC). This is evidenced by the significant value of CSR simultaneously (Test $\mathrm{f}$ ) of 0.001 or less than 0.05 . While the significance of CSR partially ( $t$ test) of 0.489 or greater than 0.05 . It is concluded that CSR simultaneously affect the earnings quality. However, CSR is partially no effect on earnings quality through discretionary accruals (DAC). While the control variables in this study such as firm size and leverage does not affect the quality of earnings. While the profitability variable effect on earnings quality.
\end{abstract}

Keywords: Earnings Quality, Corporate Social Disclosure, Firm Size, Leverage and Profitability 


\section{Pendahuluan}

Kualitas laba umumnya mengacu pada kemampuan laba yang dilaporkan untuk mencerminkan pendapatan perusahaan yang sebenarnya, serta kepatuhan dari laba yang dilaporkan untuk memprediksi laba masa depan. Kualitas laba juga mengacu pada stabilitas, ketekunan, dan kurangnya variabilitas dalam laba yang dilaporkan. Laba yang berkualitas maka investor akan memberikan sinyal positif melalui kesediannya menanamkan sahamnya yang tentunya akan mendorong kelangsungan hidup suatu perusahaan (Lassad dan Khamoussi, 2012). Dalam laporan tahunan perusahaan, corporate social responsibility ini tentunya menjadi salah satu strategi bisnis perusahaan untuk meningkatkan kualitas labanya. Perusahaan yang melakukan CSR dengan baik lebih mungkin melaporkan kualitas laba yang diinginkan oleh investor daripada perusahaan lain. Pengungkapan aktivitas CSR oleh perusahaan menjadi tolak ukur transparansi pelaporan keuangan dan merupakan salah satu bentuk pertanggungjawaban yang diberikan perusahaan kepada stakeholder. Manajemen laba yang tinggi akan menghasilkan kualitas laba yang rendah sedangkan manajemen laba yang rendah akan menghasilkan kualitas laba yang tinggi. Kualitas laba adalah sebuah dimensi utama dari kualitas pelaporan keuangan. Salah satu alasan manajemen melakukan pelaporan sosial adalah untuk alasan strategis dimana kegiatan CSR dapat dijadikan tameng bagi manajemen untuk memanipulasi pendapatan (manajemen laba) (Muttakin et al., 2015).

Di Indonesia, praktik CSR telah mendapat perhatian yang cukup besar. Hal ini dilatarbelakangi oleh berbagai kasus yang tejadi seperti penggundulan hutan, meningkatnya polusi dan limbah, buruknya kualitas dan keamanan produk, eksploitasi sumber daya alam yang berlebihan, dan lainnya. Selain itu, dikeluarkannya beberapa peraturan pemerintah juga mendorong praktik dan pengungkapan CSR di Indonesia. Regulasi mengenai CSR telah diatur oleh pemerintah sejak tahun 1994 dengan dikeluarkannya keputusan Menteri Keuangan Republik Indonesia No.316/KMK 016/1994, keputusan menteri negeri badan usaha milik negara No.Kep-236/MBU/2003, pasal 15b Undang- Undang No.25 Tahun 2007. Alasan pemilihan pengungkapan CSR pada sektor pertambangan karena kegiatan eksplorasi dan eksplotasi sumber daya yang terbatas di Indonesia yang menimbulkan masalah lingkungan seperti kesenjangan sosial antara masyarakat dengan perusahaan.Seperti kasus pencemaran biota laut oleh PT. Freeport Indonesia yang dinilai tidak memenuhi batas air limbah.

\section{Landasan Teori Dan Pengembangan Hipotesis}

\subsection{Landasan Teori}

Menurut Freeman (1984), stakeholder didefinisikan sebagai sebuah organisasi, grup atau individu yang dapat dipengaruhi dan mempengaruhi tujuan organisasi tersebut. Perusahaan harus menjaga hubungan dengan mengakomodasi keinginan dan kebutuhan stakeholder-nya. Konsep stakeholder memiliki dua model yaitu model kebijakan dan perencanaan bisnis serta model tanggung jawab sosial perusahaan dari manajemen stakeholder. Pada model pertama, fokusnya adalah mengembangkan dan mengevaluasi persetujuan keputusan strategis perusahaan dengan kelompok kelompok yang dukungannya diperlukan untuk kelangsungan usaha perusahaan. Dapat dikatakan bahwa model ini berfokus pada cara - cara yang dapat digunakan oleh perusahaan untuk mengelola hubungan perusahaan dengan stakeholder-nya. Sementara dalam model kedua, perencanaan perusahaan dan analisis diperluas dengan memasukkan pengaruh eksternal yang mungkin berlawanan bagi perusahaan. Kelompok-kelompok yang berlawanan ini termasuk badan regulator (government) dengan kepentingan khusus yang memiliki kepedulian terhadap permasalahan sosial.

Selanjutnya penelitian ini juga menggunakan teori legitimasi dimana memfokuskan pada interaksi antara perusahaan dengan masyarakat. Legitimasi masyarakat merupakan faktor strategis bagi perusahaan dalam rangka mengembangkan perusahaan kedepan dengan membina hubungan dengan masyarakat dan lingkungan disekitar perusahaan (Titisari et al., 2010). Teori legitimasi ini dapat diterapkan pada perusahaan yang melakukan kegiatan tanggung jawab sosial. Dampak yang ditimbulkan dari aktivitas perusahaan tersebut, akan sangat berpengaruh terhadap masyarakat sekitar, sehingga apa yang dilakukan oleh pihak perusahaan akan kembali lagi kepada masyarakat tersebut. Oleh karena itu, manajemen perusahaan membutuhkan dukungan dari lingkungan masyarakat yang kondusif agar perusahaan dapat beroperasi dengan tenang.

Pada teori signal melibatkan dua pihak, yaitu pihak dalam seperti manajemen yang berperan sebagai pihak yang memberikan sinyal dan pihak luar seperti investor yang berperan sebagai pihak 
yang menerima sinyal tersebut. Spence mengatakan bahwa dengan memberikan suatu isyarat atau sinyal, pihak manejemen berusaha memberikan informasi yang relevan yang dapat dimanfaatkan oleh pihak investor. Pada waktu informasi diumumkan dan semua pelaku pasar sudah menerima informasi tersebut, pelaku pasar terlebih dahulu menginterpretasikan dan menganalisis informasi tersebut sebagai sinyal baik (good news) atau sinyal buruk (bad news). Dalam hal ini, Kualitas pelaporan keuangan merupakan sinyal bagi pasar keuangan dan pemangku kepentingan lainnya bahwa manajemen dapat dipandang mampu mengendalikan risiko sosial dan lingkungan di dalam perusahaan. Selain itu, pengungkapan sosial perusahaan memberi isyarat kepada investor dan pemangku kepentingan ekonomi dan kuat lainnya bahwa perusahaan secara aktif mengambil bagian dalam praktik CSR dan bahwa nilai pasarnya dalam posisi yang baik (Cormier, Ledoux dan Magnan, 2011).

\subsection{Pengembangan Hipotesis}

Dalam menganalisis pengaruh pengungkapan corporate social responsibility terhadap earnings quality yang diproksikan melalui manajemen laba sebagai variable dependen. Penelitian ini juga menggunakan tiga variabel kontrol yaitu firm size, leverage,dan profitability ratio. Corporate Social Responsibility sangat penting kaitannya dengan keberlanjutan perusahaan karena merupakan tanggungjawab moral perusahaan terhadap masyarakat. Namun, pengungkapan CSR juga seringkali dianggap untuk menyembunyikan perilaku buruk perusahaan melalui pelaporan kualitas laba yang buruk. Kualitas laba menjadi cerminan dari suatu perusahaan terkait dengan perilaku oportunistik yang dilakukan oleh seorang manajer. Litt (2013) menemukan pengaruh negatif signifikan inisiatif kepedulian lingkungan terhadap manajemen laba. Hasil penelitian menyatakan secara tidak langsung bahwa perusahaan yang menggaet lingkungan memiliki tatakelola yang baik dan budaya perusahaan yang kuat sehingga meminimalisasi manajemen pajak. Ukuran perusahaan merupakan skala pengukuran dapat dikelompokkan menjadi skala kecil, menengah dan besar. Dasar pengukuran tersebut dilihat dari jumlah total aset perusahaan atau total penjualan. Perusahaan yang memiliki ukuran perusahaan yang besar akan mendorong adanya kualitas laba yang meningkat. Besaran perusahaan dapat berpengaruh negative terhadap kualitas laba. Hal demikian dapat terjadi pada perusahaan besar karena cenderung menggunakan prosedur akuntansi menurunkan laba (incomedecresing).

Leverage diperoleh melalui total utang dibagi dengan total equity yang mencerminkan kemampuan perusahaan dalam memenuhi seluruh kewajibannya yang ditunjukkan oleh beberapa bagian modal sendiri yang digunakan untuk membayar utang. Perusahaan yang memiliki utang besar, memiliki kecenderungan melanggar perjanjian utang jika dibandingkan dengan perusahaan yang memiliki utang lebih kecil. Apabila, semakin besar kewajiban yang menjadikan manajemen perusahaan menajdi sulit dalam membuat prediksi jalannya perusahaan kedepan. Utang dapat meningkatkan manajemen laba saat perusahaan ingin mengurangi kemungkinan pelanggaran perjanjian utang (Klein, 2002). Rasio profitabilitas yang diporoksikan dengan ROA menunjukkan kemampuan manajemen dalam menghasilkan laba dengan memanfaatkan aktiva yang digunakan dalam kegiatan operasi. Semakin besar perubahan ROA menunjukkan semakin besar fluktuasi kemampuan manajemen dalam menghasilkan laba. Hal ini mempengaruhi investor dalam memprediksi laba dan memprediksi risiko dalam investasi sehingga memberikan dampak padakepercayaan investor terhadap perusahaan.

H1. Corporate Social Responsibility (CSR) berpengaruh terhadap earnings quality perusahaan.

Gambar 1.1

Model Penelitian

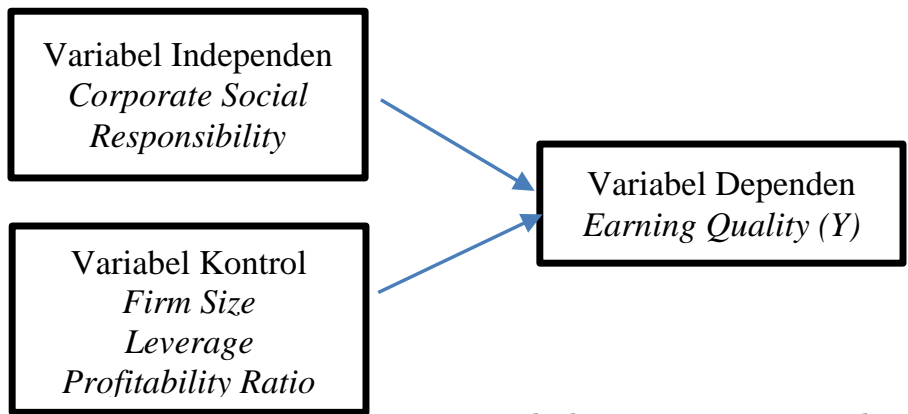

$\mathrm{Vol}: 8$, no 1,2020

Jurnal Akuntansi Keuangan dan Perpajakan Indonesia 


\section{Metode Penelitian}

\subsection{Populasi Dan Pemilihan Sampel}

Populasi (population) mengacu pada keseluruhan kelompok orang, kejadian, atau hal- hal menarik yang ingin peneliti investigasi. Populasi dalam penelitian ini adalah seluruh perusahaan yang bergerak di bidang pertambangan yang diklasifikasikan berdasarkan yang terdaftar di Bursa Efek Indonesia pada periode 2015-2017. Selanjutnya, sampel dianalisis berdasarkan analisis deskriptif dengan menggunakan uji asumsi klasik, uji normalitas, uji multikolineritas, uji heteroskedastisitas, uji autokorelasi, analisis regresi berganda, uji statistik F, uji statistik T, dan Koefisien Determinasi (R2). Selajutnya pemilihan sampel menggunakan metode purposive sampling, maka jumlah sampel yang digunakan sebanyak 12 perusahaan yang terseleksi dengan waktu pengamatan 3 tahun menjadi 36 perusahaan. Sebanyak 17 perusahaan dikeluarkan karena tidak memiliki data laporan tahunan (annual report) dan laporan keuangan untuk tahun pelaporan 2015-2017. Serta sebanyak 13 perusahaan yang mengungkapkan item- item aktivitas corporate social responsibility $(C S R)$ berturut- turut selama tiga tahun mulai dar periode 2015- 2017. Pengambilan sampel sesuai dengan kualifikas sebagai objek penelitian berdasarkan kriteria yang telah ditetapkan. Kriteria sampel yang digunakan dalam penelitian ini adalah sebagai berikut :

$$
\text { NDAit }=\beta 1(1 / \text { Ait-1 })+\beta 2\left(\frac{A_{\text {REVit }}-1}{\text { ARECit }} / \text { Ait-1 }\right)+\beta 3\left(\frac{\text { PPEit }}{\text { Ait-1 }}\right)+\text { zit }
$$

\section{Tabel 1}

Pemilihan Sampel

\begin{tabular}{|c|l|c|}
\hline No. & \multicolumn{1}{|c|}{ Kriteria Sampel } & Akumulasi \\
\hline 1 & $\begin{array}{l}\text { Perusahaan pertambangan yang telah terdaftar di Bursa Efek Indonesia sejak } \\
\text { tahun 2015 dan tetap terdaftar sampai dengan 2017. }\end{array}$ & 42 \\
\hline 2 & $\begin{array}{l}\text { Perusahaan yang tidak memiliki data laporan tahunan (annual report) dan } \\
\text { laporan keuangan untuk tahun pelaporan 2015-2017. }\end{array}$ & $(17)$ \\
\hline 3 & $\begin{array}{l}\text { Perusahaan yang mengungkapkan item- item aktivitas corporate social } \\
\text { responsibility (CSR) berturut- turut selama tiga tahun mulai dar periode 2015-2017. }\end{array}$ & $(13)$ \\
\hline Jumlah sampel terseleksi & $\mathbf{1 2}$ \\
\hline Jumlah Sampel yang Terseleksi dikali 3 Tahun Pengamatan & $\mathbf{3 6}$ \\
\hline
\end{tabular}

\subsection{Definisi Operasional Dan Pengukuran Variabel}

\subsubsection{Earnings Quality (Kualitas Laba)}

Earnings quality (Y) adalah suatu tingkat dimana laba dapat merefleksikan dampak ekonomis yang sesungguhnya dari suatu transaksi. Earnings quality dalam penelitian ini diproksikan dengan manajemen laba. Manajemen laba yang tinggi akan menghasilkan kualitas laba yang rendahsedangkan manajemen laba yang rendah akan menghasilkan kualitas laba yang tinggi. Hal tersebut dapat dapat dideteksi dengan pengujian atas komponen akrual diskresioner. Manajemen laba dalam penelitian ini diukur menggunakan proksi discretionary accrual (DAC) dari model Jones yang dimodifikasi (Modified Jones Model) antara lain dalam menghitung nilai total akrual dengan menggunakan pendekatan arus kas (cash flow approach) yaitu

\section{TAit $=$ NIit - CFOit}

dimana: TAit : Total akrual perusahaan i pada tahun ke $\mathrm{t}$;

NIit : Laba bersih setelah pajak perusahaan i pada tahun ke $t$;

CFOit : Arus kas operasi perusahaan i pada tahun ke t.

Untuk mencari nilai koefisien $\beta 1, \beta 2$ dan $\beta 3$ dilakukan dengan teknik regresi. Regresi ini adalah untuk mendeteksi adanya discretionary accruals dan non discretionary accruals. Discretionay accrual merupakan perbedaan antara total akrual dengan nondiscretionary accrual yaitu

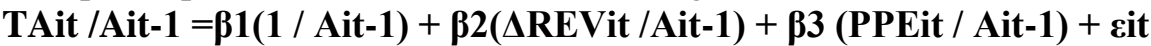

dimana TAit : Total akrual perusahaan pada tahun $\mathrm{t}$;

Ait-1 : Total aset perusahaan pada akhir tahun $\mathrm{t}-1$;

$\triangle$ REVit : Perubahan total pendapatan pada tahun t;

PPEit : Property, Plant, and Equipment perusahaan pada tahun t; 
$\beta 1, \beta 2, \beta 3$ : Parameter yang diperoleh dari persamaan regresi;

Eit : Error item.

Sedangakan untuk perhitungan nondiscretionary Accruals (NDAC) dilakukan dengan memasukkan nilai koefisien $\beta 1, \beta 2$, dan $\beta 3$ yang diperoleh dari regresi yaitu dimana: NDAit:Nondiscretionary acrruals perusahaan pada tahun t; $\triangle$ RECit: Perubahan piutang perusahaan pada tahun t. Setelah didapatkan nilai nondiscretionary accruals, menghitung discretionary accruals dapat dilakukan menggunakan persamaan berikut:

DAit $=($ TAit/Ait-1) - NDAit,

dimana: DAit : Discretionary Accruals perusahaan dalam tahun t.

\subsubsection{Coporate Social Responsibility (CSR)}

Coporate Social Responsibility merujuk pada semua hubungan yang terjadi antara sebuah perusahaan dengan semua stakeholders, termasuk pelanggan atau customers, pegawai, komunitas, pemilik atau investor, pemerintah, supplier, bahkan juga competitor. Dalam penelitian ini Coporate Social Responsibility (CSR) diukur dengan menggunakan Coporate Social Responsibility Disclosure Index (CSRDI) berdasarkan Reporting Initiatives Generation 3.1 (GRI G3.1) yang diperoleh dari website www.globalreporting.org . Berikut indikator index GRI G3.1 antara lain:

Tabel 2

Indikator Index GRI G3.1

\begin{tabular}{|c|l|c|}
\hline No & \multicolumn{1}{|c|}{ Indikator } & Jumlah Item \\
\hline 1 & Kinerja Ekonomi (Economic Performance) & 9 \\
\hline 2 & Kinerja Lingkungan (Environmental Performance) & 30 \\
\hline 3 & Praktik Kerja (Decent Work Performance) & 14 \\
\hline 4 & Hak Manusia (Human Rights Performance) & 9 \\
\hline 5 & Sosial (Society Performance) & 8 \\
\hline 6 & Tanggungjawab Terhadap Produk (Product Responsibility Performance) & 9 \\
\hline \multicolumn{2}{|c|}{ Total Item } & $\mathbf{7 9}$ \\
\hline
\end{tabular}

Dalam menghitung CSR menggunakan dimana, CSRDIj: Corporate Social Responsibility Disclosure Index perusahaan; $N$ : Jumlah item untuk perusahaan, $n=79 ; X i j: 1=$ jika item i diungkapkan, $0=$ jika item i tidak diungkapkan.

$$
\operatorname{CSRDI}_{\mathbf{J}}=\frac{\sum \mathrm{xij}}{\mathbf{n j}}
$$

\subsubsection{Firm Size, Leverage, dan Profitability Ratio}

Ukuran perusahaan merupakan skala pengukuran dapat dikelompokkan menjadi skala kecil, menengah dan besar. Perusahaan yang memiliki ukuran perusahaan yang besar akan mendorong adanya kualitas laba yang meningkat. Dasar pengukuran tersebut dilihat dari jumlah total aset perusahaan atau total penjualan dengan rumus: $F S I Z E=\log$ (TotalAset). Selanjutnya dalam penelitian ini leverage digunakan untuk mengetahui seberapa besar aset perusahaan dibiayai oleh hutang. Leverage mencerminkan tingkat risiko keuangan dan laba yang akan diperoleh perusahaan. Semakin tinggi tingkat leverage perusahaan menyebabkan semakin rendah kualitas laba dengan rumus:

$$
\text { Lev }=\frac{\text { Total Hutang }}{\text { Total Ekuitas }}
$$

Selanjutnya, profitabilitas merupakan kemampuan perusahaan dalam meghasilkan laba melalui asset. Tingkat profitabilitas dapat dijadikan sebagai dasar pengambilan keputusan investasi. yang dimilikinya. Semakin tinggi tingkat profitabilitas perusahaan maka semakin baik signal bagi investor 
untuk tetap mempertahankan sahamnya pada perusahaan. Semakin tinggi profitabilitas perusahaan maka kualitas laba akan semakin kuat. Profitabilitas dalam penelitian ini menggunkan Return on Assets (ROA). ROA digunakan umtuk mengukur kemampuan manajemen dalam memperoleh keuntungan (laba) secara keseluruhan. Variabel profitability ratio (ROA) dapat dirumuskan sebagai berikut:

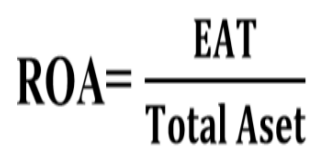

\subsection{METODE ANALISIS DATA}

Analisis data merupakan suatu proses penyederhanaan data kedalam bentuk yang lebih mudah dibaca dan di interpretasikan. Dengan menggunakan metode kuantitatif, diharapkan akan didapatkan hasil pengukuran yang lebih akurat tentang respon yang diberikan oleh responden. Analisis data, terlebh dahulu dilakukan analisis statistik deskriptif untuk menganalisis data dengan cara menggambarkan sampel data yang telah dikumpulkan dalam kondisi sebenarnyatanpa maksud membuat kesimpulan yang berlaku umum atau generalisasi. Selanjutnya uji normalitas, dimana uji ini untuk melihat apakah nilai residual terdistribusi normal atau tidak. Uji normalitas bertujuan untuk menguji apakah dalam model regresi, variabel pengganggu atau residual memiliki distribusi normal. Dasar pengambilan keputusan untuk uji normalitas yaitu: apabila Signifikansi > 0,05 (Ho diterima: data normal) sedangkan Signifikansi < 0,05 (Ha ditolak: data tidak normal).

Selanjutnya uji multikolinearitas digunakan untuk menguji apakah dalam model regresi terdapat hubungan antara variabel bebas/independen karena model regresi yang baik seharusnya tidak terjadi korelasi antara variabel bebas independen. Untuk mendeteksi ada tidaknya multikolonieritas yaitu Jika nilai tolerance lebih kecil< dari 0,10 atau VIF lebih besar > dari 10, maka menunjukkan adanya multikolinearitas. Sebaiknya jika nilai tolerancenya lebih besar (>) dari 0,10 atau nilai VIF lebih kecil (<) dari 10, maka tidak ada multikolineritas. Uji heteroskedasitas bertujuan menguji apakah dalam model regresi terjadi ketidaksamaan variance dari residual satu pengamatan ke pengamatan lain. Salah satu uji yang dapat dilakukan dengan melihat gambar plot antara nilai prediksi variabel independen (ZPRED) dengan residual (SRESID).Apabila dalam grafik tersebut tidak terdapat pola tertentu yang teratur dan data tersebar secara acak diatas dan dibawah angka 0 pada sumbu Y, maka diidentifikasikan tidak terdapat heterokedastisitas (Ghozali, 2016).

Setelah itu, model persamaan regresi dilakukan dengan rumus DAit $=\alpha+\beta 1$ CSRIit $+\beta 2$ SIZEit $+\beta 3$ LEVit $+\beta 4$ ROAit-1 + it dimana, DAit : Manajemen laba yang diukur menggunakan proksi discretionary accrual perusahaan tahun bersangkutan; CSRIit : Pengungkapan CSR melalui CSR index perusahaan tahun; SIZEit : Firm Size perusahaan tahun perusahaan; LEVit : Leverage perusahaan i tahun bersangkutan; ROAit-1 : Return on Assets perusahaan pada tahun sebelumnya; A : Konstanta; $\beta 1-\beta 4$ : Koefisien regresi; dan E : Error item. Uji hipotesis terdiri dari uji simultan $\mathrm{F}$ dengan kriteria Jika Fhitung < Ftabel dan nilai signifikansi > 0,05, maka Ha ditolak dan Jika Fhitung $>$ Ftabel dan nilai signifikansi < 0,05 maka Ha diterima. Sedangkan uji statistik t dianalisis dengan kriteria Jika nilai signifikansi (sig) lebih besar dari 0,05 maka hipotesis ditolak dan jika nilai signifikansi (sig) lebih kecil atau sama dengan 0,05 maka hipotesis diterima.

\section{Hasil Penelitian Dan Pembahasan}

\subsection{Statistik Deskriptif}

Berdasarkan statistik deskriptif dari 36 sampel perusahaan dari 3 tahun pengamatan penelitian. Berdasarkan pada tabel 4.3 menunjukkan bahwa nilai Earnings Quality yang diukur dengan akrual diskresioer menunjukkan nilai tertinggi (maximum) sebesar 15,73 dan nilai terendah (minimum) sebesar -0,08. Nilai rata-rata (mean) dari variabel dependen ini adalah 0,2144. Nilai standar deviasi (standar deviation) untuk akrual diskresioner adalah 0,15259. Variabel Corporate Social Responsibility (CSR) yang diukur dengan Coporate Social Responsibility Index (CSRI) menunjukkan nilai maximum sebesar 0,33 dan nilai minimum sebesar 0,08. Nilai mean dari variabel Coporate Social Responsibility adalah 0,1419 dan nilai standar deviation adalah 0,06018.

Selanjutnya variabel kontrol firm size menunjukkan nilai maximum sebesar 15,73 dan nilai minimum sebesar 11,50. Nilai mean dari variabel firm size adalah 12,9691dan nilai standar deviation 
adalah 1,09669. Untuk leverage menunjukkan nilai maximum sebesar 8,79 dan nilai minimum sebesar 0,11 . Nilai mean dari variabel leverage adalah 1,6512 dan nilai standar deviation adalah 2,15618 . Sedangkan untuk profitabilitas menunjukkan nilai maximum sebesar 0,36 dan nilai minimum sebesar 0,08. Nilai mean dari variabel profitabilitas adalah 0,0737 dan nilai standar deviation adalah 0 , ,10118.

\section{Tabel 3}

Hasil Statistik Deskriptif Descriptive Statistics

\begin{tabular}{|c|c|c|c|c|c|}
\hline \multicolumn{6}{|c|}{ Descriptive Statistics } \\
\hline & $\mathrm{N}$ & Minimum & Maximum & Mean & Std. Deviation \\
\hline Dait & 36 &,- 06 & ,70 & ,2144 &, 15259 \\
\hline CSRIit & 36 & 08 & 33 & ,1419 & ,06018 \\
\hline SIZEit & 36 & 11,50 & 15,73 & 12,9691 & 1,09669 \\
\hline LEVit & 36 &, 11 & 8,79 & 1,6512 & 2,15618 \\
\hline ROAit & 36 &,- 08 &, 36 & ,0737 & ,10118 \\
\hline Valid N (listwise) & 36 & & & & \\
\hline
\end{tabular}

\subsection{Uji Normalitas}

Pada dasarnya normalitas dapat dideteksi dengan melihat titik-titik (penyebaran data) pada sumbu diagonal dari grafik atau dengan cara melihat histogram dari residualnya (Ghozali, 2016). Namun, dalam penelitian ini uji normalitas data menggunakan Kolmogrov-Smirnov test. Dasar pengambilan keputusan untuk uji normalitas: Signifikansi > 0,05 (Ho diterima: data normal) dan Signifikansi < 0,05 (Ha ditolak: data tidak normal).

Tabel 4

Hasil Uji Normalitas

\begin{tabular}{|c|c|c|}
\hline \multicolumn{3}{|c|}{ One-Sample Kolmogorov-Smirnov Test } \\
\hline & & Unstandardized Residual \\
\hline \multicolumn{2}{|l|}{$\mathrm{N}$} & 36 \\
\hline \multirow{2}{*}{ Normal Parameters ${ }^{\mathrm{a}, \mathrm{b}}$} & Mean & $0 \mathrm{E}-7$ \\
\hline & Std. Deviation &, 11327817 \\
\hline \multirow{3}{*}{ Most Extreme Differences } & Absolute &, 070 \\
\hline & Positive & ,063 \\
\hline & Negative &,- 070 \\
\hline \multicolumn{2}{|l|}{ Kolmogorov-Smirnov Z } & 419 \\
\hline \multicolumn{2}{|l|}{ Asymp. Sig. (2-tailed) } & ,995 \\
\hline
\end{tabular}

a. Test distribution is Normal.

b. Calculated from data.

Berdasarkan tabel di atas, diketahui bahwa nilai signifikansi sebesar 0,995 lebih besar dari 0,05. Sehingga dari tabel tersebut dapat disimpulkan bahwa data terdistribusi secara normal.

\subsection{Analisis Regresi}

Dari tabel analisis regresi linier berganda diatas, maka dapat diketahui rumus model persamaan regresi sebagai berikut :

\begin{tabular}{|c|c|c|c|}
\hline \multirow[t]{2}{*}{ DAit $=0,49$} & \multicolumn{3}{|c|}{$\begin{array}{c}\text { Tabel } 5 \\
\text { Hasil Uji Regresi }\end{array}$} \\
\hline & \multirow[b]{2}{*}{ Model } & \multicolumn{2}{|c|}{ Unstandardized Coefficient } \\
\hline & & $\mathrm{B}$ & Std. Error \\
\hline & \begin{tabular}{l|l} 
(Constant) \\
\end{tabular} & 0,49 &, 257 \\
\hline 1 & CSRIit & $-0,254$ &, 363 \\
\hline & SIZEit &, 008 &, 019 \\
\hline & LEVit & ,013 & ,010 \\
\hline & ROAit & 1,046 & ,217 \\
\hline
\end{tabular}


Adapun interpretasi regresi berganda di atas dapat dijelaskan sebagai berikut:

Konstanta sebesar 0,49 menyatakan apabila corporate social responsibility, firm size, leverage, dan ROA dianggap konstan, maka nilai perusahaan adalah sebesar 0,49. Koefisien regresi CSRI sebesar 0,254 menyatakan bahwa setiap peningkatan CSRI sebesar 1 akan menurunkan DAit sebesar -0,254. Koefisien regresi SIZE sebesar 0,008 menyatakan bahwa setiap peningkatan SIZE sebesar 1 akan meningkatkan DAit sebesar 0,008. Koefisien regresi LEV sebesar 0,013 menyatakan bahwa setiap peningkatan LEV sebesar 1 akan meningkatkan DAit sebesar 0,013. Koefisien regresi ROE sebesar 1,046 menyatakan bahwa setiap peningkatan ROE sebesar 1 akan meningkatkan DAit sebesar 1,046.

\subsection{Uji Simultan (Uji F)}

Hasil pengujian uji simultan (uji F) dalam penelitian ini ditunjukkan dalam tabel di bawah:

Tabel 6

Hasil Uji Simultan (Statistk F)

\begin{tabular}{rlrrrrr}
\hline \multicolumn{7}{c}{ ANOVA $^{\mathbf{a}}$} \\
\hline Model & Sum of Squares & \multicolumn{1}{c}{ Df } & Mean Square & F & \multicolumn{1}{c}{ Sig. } \\
\hline \multirow{2}{*}{1} & Regression &, 366 & 4 &, 091 & 6,312 &, $001^{\text {b }}$ \\
& Residual &, 449 & 31 &, 014 & & \\
& Total &, 815 & 35 & & & \\
\hline
\end{tabular}

a. Dependent Variable: Dait

b. Predictors: (Constant),ROAit, CSRIit,SIZEit, LEVit,

Berdasarkan hasil pengolahan SPSS pada tabel 4.9 diatas, dapat dilihat bahwa $F_{\text {hitung }}$ adalah sebesar 6,312. Nilai Ftabel pada $\alpha=0,05$ adalah kombinasi dari $\mathrm{k}=4$ dan df: $\mathrm{n}-\mathrm{k}=36-4=32$ sebesar 2,67. Hal ini menunjukkan nilai $\mathrm{F}_{\text {hitung }} 6,312>\mathrm{F}_{\text {tabel }} 2,67$ sedangkan nilai signifikansi sebesar $0,001<0,05$. Maka dapat disimpulkan bahwa corporate social responsibility, firm size, leverage, dan ROA terdapat berpengaruh secara simultan (bersama - sama) terhadap variabel dependen, yaitu earnings quality melalui akrual diskresioner.

\subsection{Uji Parsial (Uji t)}

Dapat dilihat bahwa Nilai $\mathrm{T}_{\text {tabel }}$ pada $\alpha=0,05$; dengan df: $\mathrm{n}-(\mathrm{k}+1)$; 36- $(4+1)=31$ uji dua arah adalah sebesar 2,03951, maka dapat dijelaskan sebagai berikut : Berdasarkan uji hipotesis $\mathrm{t}$ menunjukkan nilai $\mathrm{T}_{\text {hitung }}-0,700<$ nilai $\mathrm{T}_{\text {tabel }} 2,03951 \quad(-0,700<2,03951)$ dan nilai signifikansi 0,489>0,05. Hal ini menunjukkan bahwa CSRI tidak berpengaruh terhadap kualitas laba melalui akrual diskresioner. Hasil uji t pada variabel SIZE menghasilkan nilai $\mathrm{T}_{\text {hitung }} 0,409<$ nilai $\mathrm{T}_{\text {tabel }} 2,03951$ $(0,409<2,03951)$ dan nilai signifikansi $0,685>0,05$, yang berarti variabel SIZE tidak berpengaruh terhadap kualitas laba melalui akrual diskresioner.

Hasil uji t pada variabel LEV menghasilkan nilai $T_{\text {hitung }} 1,220<$ nilai $T_{\text {tabel }} 2,03951 \quad(1,220$ $<2,03951$ ) dan nilai signifikansi 0,232>0,05, yang berarti variabel LEV tidak berpengaruh terhadap kualitas laba melalui akrual diskresioner.Hasil uji t pada variabel ROA menghasilkan nilai $\mathrm{T}_{\text {hitung }}$ $4,822>$ nilai $\mathrm{T}_{\text {tabel }} 2,03951 \quad(4,822>2,03951)$ dan nilai signifikansi $0,000<0,05$, yang berarti variabel ROA berpengaruh dan signifikan terhadap kualitas laba melalui akrual diskresioner.

Tabel 7

Hasil Uji Parsial

Coefficients $^{\mathrm{a}}$

\begin{tabular}{|c|c|c|c|c|c|}
\hline \multirow[t]{2}{*}{ Model } & \multicolumn{2}{|c|}{$\begin{array}{c}\text { Unstandardized } \\
\text { Coefficients }\end{array}$} & $\begin{array}{l}\text { Standardized } \\
\text { Coefficients }\end{array}$ & \multirow[t]{2}{*}{$\mathrm{T}$} & \multirow[t]{2}{*}{ Sig. } \\
\hline & B & $\begin{array}{l}\text { Std. } \\
\text { Error }\end{array}$ & Beta & & \\
\hline (Constant) & ,049 &, 257 & & 192 & 849 \\
\hline CSRIit &,- 254 & 363 &,- 100 &,- 700 & 489 \\
\hline SIZEit & ,008 & 019 & ,057 & ,409 & ,685 \\
\hline LEVit & ,013 & , 010 & , 180 & 1,220 & 232 \\
\hline ROAit & 1,046 & ,217 & 694 & 4,822 & ,000 \\
\hline
\end{tabular}

a. Dependent Variable: DAit 


\section{Kesimpulan Dan Keterbatasan Penelitian \\ 5.1 Kesimpulan}

Hasil analisis penelitian dapat dibuktikan bahwa CSR tidak berpengaruh terhadap kualitas laba melalui akrual diskresioner. Hasil ini sesuai dengan penelitian yang dilakukan oleh Kim, Park, dan Wier (2012) dan Bonzollan, Fabrizi, Mallin, dan Michelon (2013) dimana perusahaan yang semakin besar berkontribusi terhadap CSR akan lebih berhati-hati dalam melaporkan laporan keuangan yang ditujukan untuk kepentingan stakeholder karena CSR dianggap sebagai suatu kewajiban moral yang mampu membentuk karakter perilaku manajer untuk berperilaku jujur, beretika ,dapat dipercaya serta patuh terhadap standar yang berlaku dalam menjalankan bisnis sehingga perusahaan lebih mungkin untuk menghindari atau mengurangi manipulasi laba. Dengan demikian perusahaan yang berkontribusi terhadap CSR akan menghasilkan kualitas laba yang baik.

Tetapi hasil penelitian ini kontradiktif dengan hasil penelitian yang telah dilakukan Prior et al. (2008) dan Salewski et al. (2014), yang menemukan pengaruh positif antara CSR dengan earnings management, yaitu semakin baik CSR semakin tinggi tingkat aktivitas manajemen laba. Berdasarkan uji hipotesis $\mathrm{t}$ untuk firm size (SIZE) dan leverage (LEV) menunjukkan bahwa nilai $\mathrm{T}_{\text {hitung }}$ lebih kecil dari nilai $\mathrm{T}_{\text {tabel }}$ dan nilai signifikansi lebih besar dari 0,05 yang berarti bahwa variabel pengungkapan CSR tidak terbukti dan tidak berpengaruh secara signifikan terhadap kualitas laba melalui akrual diskresioner (Discretioner accruals). Sedangkan untuk variabel profitabilitas (ROA) menunjukkan bahwa nilai $\mathrm{T}_{\text {hitung }}$ lebih besar dari nilai $\mathrm{T}_{\text {tabel }}$ dan nilai signifikansi lebih kecil dari 0,05 yang berarti bahwa variabel pengungkapan ROA berpengaruh secara signifikan terhadap kualitas laba melalui akrual diskresioner (Discretioner accruals).

\subsection{Saran}

Penelitian selanjutnya disarankan agar untuk memperpanjang periode pengamatan pada penelitian, saran bagi perusahaan agar lebih meningkatkan pengungkapan CSR dalam CSR report atau sustainability report, seperti pengungkapan dimensi hak azasi manusia, dimensi masyarakat dan dimensi tanggung jawab produk yang masih belum sepenuhnya diungkapkan. serta saran bagi regulator, agar dapat membuat kebijakan atau aturan mengenai perlunya audit atas program CSR untuk meminimalkan adanya gap antara laporan CSR atau sustainability report suatu perusahaan dengan kinerja nyata program CSR di lapangan.

\section{Daftar Pustaka}

Arief, A., Ardiyanto M, D. 2014. Pengaruh Pengungkapan Corporate Social Responsibility Terhadap Manajemen Laba.Volume 3, Nomor 3, Tahun 2014, Halaman 1-9, ISSN (Online): 23373806.

Assih, Prihat dan M. Gudono. 2000. Hubungan Tindakan Perataan Labadengan Reaksi Pasar atas Pengumuman Informasi Laba Perusahaan yang Terdaftar di Bursa Efek Jakarta. Simposium Nasional Akuntansi II.

Bidhari, Sandhika Cipta, et al. 2013. Effect of Corporate Social Responsibility Information Disclosure on Financial Performance and Firm Value in Banking Industry Listed at Indonesia Stock Exchange. European Journal of Business and Management, Vol. 5, No. 18, 3946.

Bougie R., Sekaran U. 2017. Metode Penelitian untuk Bisnis. Edisi 6. Buku Satu. Jakarta Selatan: Penerbit Salemba Empat.

Bougie R., Sekaran U. 2017. Metode Penelitian untuk Bisnis. Edisi 6. Buku Dua. Jakarta Selatan: Penerbit Salemba Empat.

Bozzolan S, M., Fabrizi M., Mallin C, A., Michelon G. 2013. Corporate Socia Responsibility and Earnings Quality: International Evidence. http:/dx.doi.org/10.1016/j.intcc.2015.10.003

Carroll A, B. 1991. The Pyramid of Corporate Social Responsibility: Toward the Moral Management of Organizational Stakeholders. Business Horizons 34(4):39-48. 
Cormier D., Ledoux M, J., Magnan M. 2011. The Information Contribution of Social and Enviromental Disclosures for Investors. Article in Management Decision 49(8).

Chih, H. et.al. 2008. Corporate Social Responsibility, Investor Protection, and Earnings Management: Some International Evidence. Journal of Business Ethics, Vol. 79 (2), pp. 179-198.

Dwitiya, T. 2016. Pengaruh Pengungkapan Corporate Social Responsibility Terhadap Kualitas Laba Pada Perusahaan yang Terdaftar di Bursa Efek Indonesia. Skripsi. FakultasEkonomikaUniversitasDiponegoro.

Freeman, R. E. 1984.Strategic Management: A Stakeholder Approach. Pitman Publishing. Boston

Gargouri, R. M., Shabau, R., \& Franceur, C. 2010. The Relationship Between Corporate Social Peformance and Earnings Management. Canadian Journal of Administrative Science/Revue Canadienne des Science de I'Administration, 27(4), 320-334

Grass-Gil, Ester, Palacious, M., \& Fernandez J, H. 2016. Investigating the Relationship Between Corporate Social Responsibility and Earnings Management. Evidence FromSpain.Business Research Quaterly, Vol. 19 pp 289- 299.

Ghozali, I. 2016. Aplikasi Analisis Multivariat dengan Program IBM SPSS 19 (Applications of Multivariate Analysis with IBM SPSS 23). Semarang: BP UniversitasDiponegoro.

Ghozali, I., dan Chariri, A. 2007. Teori Akuntansi. Badan Penerbit Universitas Diponegoro, Semarang

Global Reporting Initiative. 2012. Sustainability report. Retrieved from http://www.globalreporting.org.

Grecco M, C., Geron C, M., \&Grecco G, B. 2017. Corporate Social Responsibility and Its Relation With Performance and Earnings Management.v. 28, n. 1, jan/abr. 20, ISSN 0103-734X.

Guthrie, J., Parker L, D.1989. Corporate Social Reporting: A Rebuttal of Legitimacy Theory. Arcoutringortd Busiflc s.s Rcsrardi. Vol:19. No. 16. pp. 343-352. 1989.

Healy, P. M. \& Wahlen, J. M. 1999. A Review of The Earnings Management Literature And Its Implications For Standar d Setting.Accounting Horizons, 13 (4), 365-383.

Hong, Y., Andersen, M.L., 2011. The relationship between corporate social responsibility and earnings management: an exploratory study. Journal of Business Ethics, 104, 461-471.

Ikhsan A., Noch M, Y., Lesmana S., Ritonga P. 2016. Teori Akuntansi. Medan: Penerbit Madenatera.

Kasmir. 2013. Analisis Laporan Keuangan. Jakarta: PT Rajagrafindo Persada

Kieso, Donald E., Weygandt, Jerry J. \& Warfiedld, Terry D. 2007. Intermediate Accounting. 12th Edition. John Wiley \& Sons, Inc.

Kim S, H., Udawatte P., Yin J. 2018.The Effects of Corporate Social Responsibility on Real and Accrual-based Earnings Management: Evidence from China. Australian Accounting Review No. 00 Vol. 00 Issue 0 201. doi: 10.1111/auar.12235

Kim, Y., M.S. Park, and B. Wier. 2012. Is Earning Quality Associated with Corporate Social Responsibility?. The Accounting Review, Vol. 87 No.3: 761-796.

Klein, A. 2002. Audit Committee, Board of Director Characteristics, and Earnings Management. Journal of Accounting and Economics. Vol.33.P:375-400.

Kothari, S. P., Leone, A. J., \&Wasley, C. E. 2005. Performance matched discretionary accrual measures. Journal of accounting and economics, 39(1), 163-197.

Kurniawan A. 2014. Metode Riset untuk Ekonomi \& Bisnis. Bandung: Penerbit Alfabeta.

Laksmana, I., \& Yang, Y. 2009. Corporate citizenship and earnings attributes. Advances in Accounting, incorporating. Advances in International Accounting, 25(1), 40-48.

Lassad, B. M., \&Khamoussi, H. 2012. Environmental and Social Disclosure and Earnings Persistence. International Journal of Social Science \& Interdisciplinary Research 1, 20-42. 
Lindblom, C.K. 1994. The Implications of Organizational Legitimacy for Corporate Social Performance and Disclosure. Paper presented to the Critical Perspectives on Accounting Conference, New York.

Litt, Barri, Divesh Sharma, et al. 2013. Enviromental Initiatives and Earnings Management. Managerial Auditing Journal, Vol. 29, pp 76 - 106.

Muttakin, M. B., Khan, A., \&Azim, M. I. 2015. Corporate Social Responsibility Disclosures and Earning Quality: Are They a Reflection on Managers' Opportunistic Behavior?. Managerial Auditing Journal, 30(3), 277-298. http://dx.doi.org/10.1108/MAJ-02-2014-0997

Patten, D.M., and G. Trompeter. 2003. Corporate responses to political costs: an examination of the relation between environmental disclosure and earnings management. Journal Accounting and Public Policy, Vol. 22, No. 1:83-94.

Paulus, C. 2012. Analisis Faktor- Faktor yang Mempengaruhi Kualitas Laba. Skripsi Fakultas Ekonomi Universitas Diponegoro. Semarang.

Perdana, R. 2012. Pengaruh Firm Size, Leverage, Good Corporate Governance, dan Profitabilitas Terhadap Earnings Management pada Perusahaan Manufaktur yang Terdaftar di Bursa Efek Indonesia. Skripsi. Fakultas Ekonomika dan Bisnis Universitas Diponegoro. Semarang.

Prasojo F, B. 2017. Pengaruh Manajemen Laba Terhadap Corporate Social Responsibility (CSR) Berbasis Website. Skripsi. Fakultas Ekonomi Universitas Sanata Dharma.

Prior D., Tribo J, A., Surroca, J. 2008. Are Socially Responsible Managers Really Ethical? Exploring the Relationship Between Earnings Management and Corporate Social Responsibility. Article in Corporate Governance An International Review 16(3): 160-1777

Rahmawati, Dianita S, P. 2011. Analysis of the Effect of Corporate Social Responsibility on Financial Performance With Earnings Management as a Moderating Variable. Vol. 7, No. 10, 10341045, ISSN 1548-6583.

Subramanyan, K.R \& Wild, John J. 2010. Analisa Laporan Keuangan. Jakarta: Salemba Empat.

Schipper, K. 1989. Commentary on Earnings Management. Accounting Horizons, 3(4), 91- 102.

Setiawati, Lilis, dan Ainun Na'im. 2000. Manajemen laba. Jurnal Ekonomi dan Bisnis Indonesia, Vol 15, No. 4, 424-441.

Spence, M. 1973. Job market signaling. Quarterly Journal of Economics 87,355-374

Scott, William R. 2003. Financial Accounting Theory. Edisike 3. Prentice Hall Inc. Ontario. Canada.

Watts, Ross ,\& Zimmerman. 1990. Positive Accounting Theory. A Ten Years Perspective.TheAccunting Review, Vol. 65, No. 1 pp 131- 156.

WBCSD. 2002. Corporate Social Responsibility. The WBCSD's Journey. WBCSD.

Wulandari, S. 2015. The Impact Corporate Social Responsibility on accrual earnings management and real earnings management.Volume 15 (1), P-ISSN: 1412-8969; E-ISSN: 2461-0771 Page 63 - 74

Yip, E., Van Staden, C., \&Cahan, S. 2011. Corporate social responsibility reporting and earnings management: The role of political costs. Australasian Accounting Business and Finance Journal, 5(3), 17.

Keputusan Menteri Keuangan Republik Indonesia No.316/KMK 016/1994

Keputusan Menteri Badan Usaha Milik Negara No. Kep-236/MBU/2003

Undang- Undang Penanaman Modal No. 25 Tahun 2007

Undang- Undang No. 40 Tahun 2007 ayat 66 (2c) tentang Perseroan Terbatas

www.globalreporting.org

www.idx.co.id 